\title{
Efficacy of Bioelectrical Impedance Analysis for the Evaluation of Physical Impairment in Chronic Low Back Pain. Results from a Cohort Study
}

\author{
Dimitrios Kechagias, Christos Chatzipapas, Makrina Karaglani, Konstantinos Tilkeridis, \\ Athanasios Ververidis, Georgios Drosos \\ Department of Orthopaedic Surgery, Faculty of Medicine, Democritus University of Thrace, University General Hospital of Alexandroupolis, \\ Alexandroupolis, Greece
}

Corresponding author: Makrina Karaglani, Department of Orthopaedic Surgery, Faculty of Medicine, Democritus University of Thrace, University General Hospital of Alexandroupolis, Alexandroupolis, Greece; E-mail: makrina.karaglani@gmail.com

Received: 4 Oct 2020 Accepted: 13 Jan 2021 Published: 31 Dec 2021

Citation: Kechagias D, Chatzipapas C, Karaglani M, Tilkeridis K, Ververidis A, Drosos G. Efficacy of bioelectrical impedance analysis for the evaluation of physical impairment in chronic low back pain. Results from a cohort study. Folia Med (Plovdiv) 2021;63(6):919-27. doi: 10.3897/folmed.63.e59311.

\begin{abstract}
Introduction: Determining the effect of body composition on chronic low back pain seems to have the potential to improve our understanding of its mechanism and to develop novel preventive and therapeutic approaches.
\end{abstract}

Aim: The purpose of the present study was to assess by electrical impedance the composition of lower extremities of individuals with chronic low back pain.

Materials and methods: One hundred and twenty-one adult participants with diagnosed chronic low back pain were recruited in this study. The study activities were divided into three phases: phase 1 - self-administered questionnaires, phase 2 - biomedical examination (including anthropometric measurements and physical function performance tests), and phase 3 - bioimpedance analysis.

Results: Our results showed that chronic low back pain differentiates the circumference of thigh and calf of the symptomatic leg. Besides, patients experience pain also in hip, thigh, and calf, which act as a barrier to patient's personal, professional, social, and recreational activities. Furthermore, patients appear with 'unstable' walking, reduced balance, and reduced general physical condition that affect all of the neuromuscular structures of the locomotor system. Interestingly, patients seem to be characterized by a tendency to deposit fat and to decrease muscle mass in the symptomatic limb regardless of the gender.

Conclusions: In the present study, we determine the profile of a patient with chronic low back pain through a variety of measurements. Chronic low back pain causes several structural changes to the symptomatic leg of the patients leading to 'unstable' walking, reduced balance, and reduced general physical condition. It is clear that further studies using bioimpedance analysis are needed to address the concerns raised by investigating a multifactorial condition such as chronic low back pain.

\section{Keywords}

bioimpedance analysis, body composition, low back pain

Copyright by authors. This is an open access article distributed under the terms of the Creative Commons Attribution License (CC-BY 4.0), 


\section{INTRODUCTION}

Chronic back pain is one of the major challenging health problems in Western societies ${ }^{1}$ and the leading cause of disability and productivity loss worldwide with a lifetime prevalence of up to $84 \%$ for the adult patient population. ${ }^{2}$ Due to its high prevalence, lower back pain has a major impact on the health care system; annually, the total cost of back pain worldwide is estimated at about billions of dollars. ${ }^{3}$ In addition to pain and disability, high muscle tension, low self-efficacy, and depression are common side effects of chronic back pain. ${ }^{4}$ Hence, it appears essential to identify effective and economical prevention options and treatments for chronic back pain and associated impairments.

Bioelectrical impedance analysis (BIA) is an easy and non-invasive method for assessing body composition, in particular fat-free mass, body fat, body cell mass, total body water, extracellular water, and intracellular water from electrical resistance. ${ }^{5}$ BIA assesses the different body composition parameters by assessing the difference of impedance of each component of the body ${ }^{5}$ in a relatively inexpensive way. BIA is reported as a favourable alternative to dual energy X-ray absorptiometry as a screening tool for sarcopenia and osteoporosis among patients with low back pain. ${ }^{6}$ Also, in a recent study, BIA was found to be beneficial for measuring trunk muscle mass in patients with low back pain. ${ }^{7}$

Changes in body composition, especially in muscle and fat mass have been associated with several health problems. It is well known that there are negative effects of excess adiposity on movement patterns and on body structure. ${ }^{8}$ On the contrary, increased fat mass is associated with high levels of low back pain intensity and disability. ${ }^{9}$ Similarly, greater fat mass and attenuated muscle mass as body composition factors were associated with chronic low back pain. ${ }^{10}$ Recently, in a large cohort of participants with low back pain, it has been reported that fat mass and distribution are associated with low back pain intensity and disability, suggesting that systemic metabolic factors associated with adiposity play a significant role in the pathogenesis of low back pain. ${ }^{11}$

Determining the effect of body composition on chronic low back pain seems to have the potential to improve our understanding of its mechanism and consequently, clarifying such mechanisms, will facilitate the developing of novel preventive and therapeutic approaches.

\section{AIM}

The main aim of the present study was to assess by electrical impedance the composition of lower extremities of individuals with chronic low back pain, in relation to anthropometric measurements, clinical examination and physical function performance tests.

\section{MATERIALS AND METHODS}

\section{Ethical statement}

This research was approved by the IRB of the authors' affiliated institutions. Each participant provided his/her verbal and written informed consents to participate in this study. Each informed consent was ensured through the appropriate information about the purpose and nature of the study as well as its consequences, benefits, and possible risks.

\section{Study subjects}

One hundred and twenty-one adult participants (40 males and 81 females), with diagnosed chronic low back pain (with an average of 3-year symptoms) were recruited in this study. The study occurred over a 12-month period between March 2017 and March 2018. The inclusion criterion was patients with persisting low back pain for at least 3 months; the exclusion criteria were: (1) patients diagnosed with large lumbar disc herniation or lumbar spinal stenosis confirmed by magnetic resonance imaging (MRI); (2) patients with difficulty standing upright because of pain, paralysis, or spinal kyphosis; (3) patients with cardiac pacemaker; and (4) patients undergone spine surgery and with artificial joints/spinal implants in the limbs and trunk.

The study activities were divided into three phases: phase 1 - the self-administered questionnaires, phase 2 the biomedical examination, and phase 3 - the bioimpedance analysis.

\section{Self-administered questionnaires}

Demographic data including age (date of birth) and gender were collected by interview, whereas height, weight, and BMI were measured. Afterwards, patients completed two self-administered pain questionnaires. Firstly, a Body Pain Chart (Fig. 1) similar to the McGill pain questionnaire ${ }^{12}$ (Questionnaire 1a) was used to determine the site of pain. Specifically, an outline of the human body on both sides with numerical labels for all the body parts was administered to patients. Secondly, a Pain Quality Questionnaire (Questionnaire 1b) was administered to patients. This questionnaire included 6 categories of questions regarding pain quality, deteriorating factors, relieving factors, 24- $h$ pain behaviour, other symptoms and other musculoskeletal problems. Lastly, the Greek FES-I questionnaire ${ }^{13}$ (Questionnaire 2) which measures the quality of life in daily activities was used. This questionnaire included 16 questions about the quality of life of a patient with chronic low back pain, such as his reflection on his daily activities and his behavior in motor activities.

Although the questionnaires were basically in a self-administered mode, a trained physiotherapist and a biologist were present to ensure standardization during the process. 

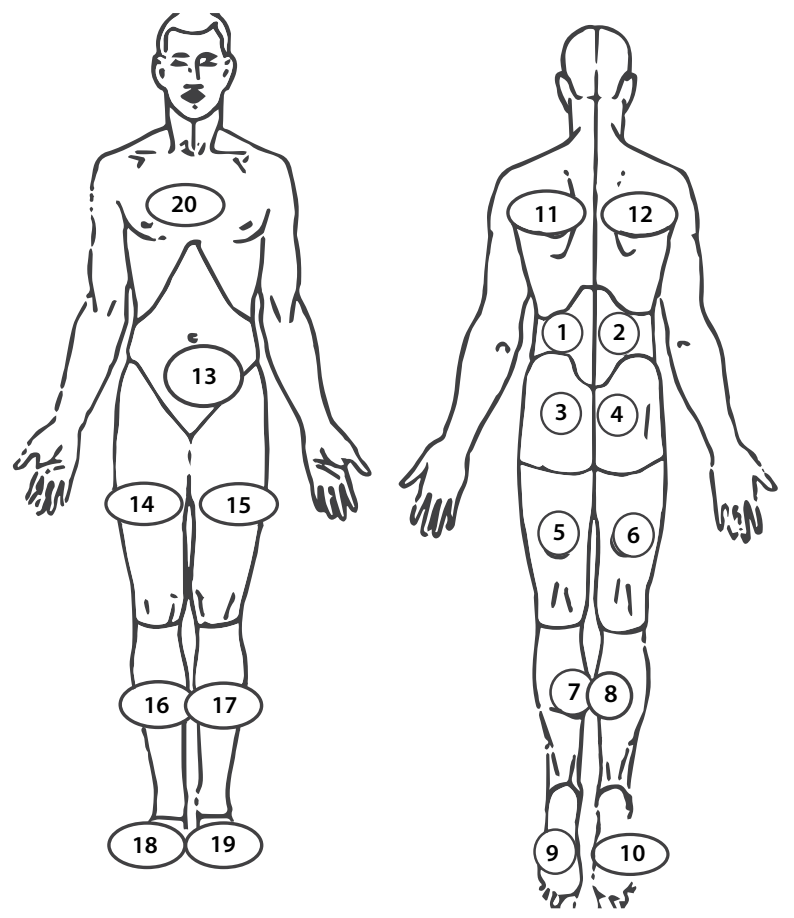

Figure 1. Body Pain Chart used in the study.

\section{Biomedical examination}

Biomedical examination included anthropometric measurements, clinical examination and physical function performance tests.

All anthropometric measurements were taken by a trained physiotherapist following standard techniques. ${ }^{14}$ Height was measured without shoes using a digital mobile stadiometer (Seca, Hamburg, Germany). Weight was measured without shoes and in light clothing using an electronic scale (Kern\&Sohn, Balingen, Germany). BMI was calculated using the standard formula: weight in kilograms divided by height in meters squared. Waist, thigh and calf circumference, and pelvic width were measured using a standard measuring tape.

Clinical examination determined the standing position, type of walking, and the pain provoking movements of the patients. In specific, posture deformities were evaluated and the standing position was characterized as normal, scoliotic, lordotic, or kyphotic. Also, movement testing included forward flexion, extension, and side flexion of the lumbar spine. Walking was determined as normal or unstable. Moreover, ability of walking on heels and on tiptoe was examined.

Furthermore, three physical function performance tests were chosen to assess the functional capacity of participants: a) the 30 -second sit-to-stand test ${ }^{15}, \mathrm{~b}$ ) the single limb stance test ${ }^{16}$, and c) the timed up and go (TUG) test ${ }^{17}$. In the 30-second sit-to-stand test the participant was seated with his back straight with one foot slightly in front of the other to help maintain balance. If he had to use his arms to complete the test, he was scored 0 . The participant was encouraged to complete as many full stands as possible within 30 seconds. The single limb stance test assesses the ability to stand on one leg as long as possible, as it is important to have a good balance to avoid a fall due to the symptomatic leg. This test is performed for both legs. The TUG test is a simple, easy-to-use functional test that can depict the mobility of patients with chronic low back pain and leg symptoms. All clinical examination and physical function performance tests were performed by trained orthopedics.

\section{Bioimpedance analysis}

The Bodystat1500 analyzer (Bodystat Ltd, British Isles) using bioelectrical impedance analysis, assessed body composition parameters, following manufacturer recommendations. Bodystat 1500 complies with all the European and US Medical Device Directives (CE Medical Devices Directive [CE 120], FDA). The subjects stood on the platform, body composition parameters were automatically calculated by flowing weak currents at $50 \mathrm{kHz}$ frequency using 2 electrodes for each side, one for the sole and one for the grip in standing barefoot position, and determining the difference in electric resistance. The analysis time is less than 20 seconds. Body composition parameters including fat mass (FM), fat free mass (FFM), total body muscle mass $(\mathrm{kg})$, total body fat mass $(\mathrm{kg})$, total body water $(\mathrm{kg})$ and basal metabolic rate (BMR) were directly calculated by Bodystat. The body weight was also measured by this device to the closest $100 \mathrm{~g}$ and a maximum weight of 300 $\mathrm{kg}$. All measurements were taken in accordance with the recommended guidelines.

\section{Statistical analysis}

T-test for paired samples was used to evaluate the difference in characteristics between symptomatic and asymptomatic legs. All continuous variables were expressed as mean $\pm \mathrm{SD}$ and categorical variables were shown as absolute and relative (percentage) frequencies. For all tests performed, statistical significance was set at two-sided $p$ value $<0.05$. Statistical analysis was carried out with the SPSS version 21.0 statistical software package for Windows (IBM - SPSS Inc., USA).

\section{RESULTS}

Forty male and eighty-one female patients (mean age $56 \pm 17$ years) with diagnosed chronic low back pain participated in our study. Of the 81 female patients, $65.4 \%$ had the left leg as symptomatic and of the 40 male patients, $90 \%$ had the left leg as symptomatic. A statistically significant increase in the circumference of the symptomatic leg's thigh was observed in relation to the asymptomatic (symptomatic thigh $0.52 \pm 0.06 \mathrm{~cm}$ vs. asymptomatic thigh: $0.51 \pm 0.06 \mathrm{~cm}, p<0.001)$. Furthermore, a statistically signifi- 
cant increase in the circumference of the symptomatic leg's calf was observed in relation to the asymptomatic (symptomatic calf $0.37 \pm 0.03 \mathrm{~cm}$ vs. asymptomatic calf $0.36 \pm 0.03$ $\mathrm{cm}, p<0.001$ ).

During clinical examination, the standing position, the walking and the pain reproduction in active lumbar spine movements were also evaluated. Regarding the standing position, $47.1 \%$ of patients presented with lordosis, $66.9 \%$ - with scoliosis, and 13.2\% - with kyphosis. All patients' walking was found to be 'unstable' in a way. $93.4 \%$ of patients experienced difficulty to walk on heels and $100.0 \%$ to walk on tiptoes. Furthermore, as far as movement testing is concerned, $93.4 \%$ of patients were feeling pain during flexion, $52.9 \%$ in extension, $73.6 \%$ in left lateral flexion, and $33.1 \%$ in right lateral flexion.

The majority of patients pointed that pain in lumbar spine was the primary cause of their pain symptoms (Table 1). In specific, they developed persistent pain on the side where the cause initially began. The hip, thigh, calf, and toes of the symptomatic leg were found to be prolonged pain points of the disease but with different rates of symptoms in the general set of patients. Also, it was found that in other areas beyond the main symptomatology of the disease such as the upper body parts (neck, shoulders, chest, and abdomen) the pain was absent.

Regarding the quality of pain, the majority of patients characterized their pain as intense or deep (Table 2). The most deteriorating factors for low back pain were found to be the walking and the standing. Whereas, the vast majority of patients felt relieved from low back pain when lying down. Regarding other musculoskeletal problems, it was found that deformations such as scoliosis, lordosis or kyphosis were present in $73.6 \%$ of patients.

The main finding of Questionnaire 2 is that pain and the related severe symptoms in both the lumbar spine and the symptomatic leg act as a barrier to the various personal, professional, social and leisure activities of the patients (Table 3).

Limb stance test was applied to both symptomatic and asymptomatic legs. Analysis of the time measurements showed a statistically significant decrease in symptomatic leg's time in relation to the asymptomatic leg $(24.07 \pm 11.37$ and $30.43 \pm 11.72$ seconds, respectively, $p<0.001)$. TUG revealed that patients with chronic low back pain had a statistically significant increase in their running time $(18.00 \pm 4.71 \mathrm{~s})$ compared to the suggested time scale of the test itself $(7-10 \mathrm{~s})(p<0.001)$. In the 30-second sit-to-stand test, the majority of patients $(56.2 \%)$ achieved 6 or more successful repeats. Following, $27.3 \%$ of patients achieved 5 repeats and $16.5 \%$ achieved 4 repeats. It is also interesting that none of the patients achieved less than three repeats.

Analysis of bioelectric impedance results showed statistically significant changes in body composition between the symptomatic and asymptomatic leg (Table 4). In specific, the mean percent of fat in the symptomatic leg was $29.85 \pm 9.51 \%$ and in asymptomatic leg $28.73 \pm 9.21 \%$,

Table 1. Questionnaire 1a: Body Pain Chart results

\begin{tabular}{lllll}
\hline Body sites & $\mathbf{N}$ & Men $(\mathbf{n = 4 0})$ & Women $(\mathbf{n = 8 1})$ & $\boldsymbol{p}$-value \\
\hline Site 1: Left lumbar spine & $89(73.6)$ & $36(90.0)$ & $53(65.4)$ & 0.004 \\
Site 2: Right lumbar spine & $44(36.4)$ & $4(10)$ & $40(49.4)$ & $<0.001$ \\
Site 3: Left hip & $81(66.9)$ & $32(80.0)$ & $49(60.5)$ & 0.032 \\
Site 4: Right hip & $28(23.1)$ & $4(10.0)$ & $24(29.6)$ & 0.016 \\
Site 5: Left posterior thigh & $45(37.2)$ & $8(20.0)$ & $37(45.7)$ & 0.006 \\
Site 6: Right posterior thigh & $16(13.2)$ & $4(10.0)$ & $12(14.8)$ & 0.462 \\
Site 7: Left calf & $49(40.5)$ & $16(40.0)$ & $33(40.7)$ & 0.938 \\
Site 8: Right calf & $20(16.5)$ & $0(0.0)$ & $20(24.7)$ & 0.001 \\
Site 9: Left foot & $17(14.0)$ & $8(20.0)$ & $9(11.1)$ & 0.186 \\
Site 10: Right foot & $4(3.3)$ & $4(10.0)$ & $0(0.0)$ & 0.004 \\
Site 11: Left shoulder & $0(0.0)$ & $0(0.0)$ & $0(0.0)$ & - \\
Site 12: Right shoulder & $0(0.0)$ & $0(0.0)$ & $0(0.0)$ & - \\
Site 13: Abdomen & $0(0.0)$ & $0(0.0)$ & $0(0.0)$ & - \\
Site 14: Left quadriceps & $4(3.3)$ & $0(0.0)$ & $4(4.9)$ & 0.153 \\
Site 15: Right quadriceps & $28(23.1)$ & $4(10.0)$ & $14(29.6)$ & 0.016 \\
Site 16: Left anterior tibialis & $24(19.8)$ & $8(20.0)$ & $16(19.8)$ & 0.974 \\
Site 17: Right anterior tibialis & $13(10.7)$ & $4(10.0)$ & $9(11.1)$ & 0.853 \\
Site 18: Left foot fingers (toes) & $16(13.2)$ & $8(20.0)$ & $8(9.9)$ & 0.122 \\
Site 19: Right foot fingers (toes) & $16(13.2)$ & $8(20.0)$ & $8(9.9)$ & 0.122 \\
Site 20: Chest, thorax & $0(0.0)$ & $0(0.0)$ & $0(0.0)$ & - \\
\hline
\end{tabular}


Table 2. Questionnaire 1b: Pain Quality Questionnaire results

\begin{tabular}{|c|c|c|}
\hline & Answers & $\begin{array}{l}\text { Results } \\
(\mathrm{n}=121)\end{array}$ \\
\hline \multirow{7}{*}{$\begin{array}{l}\text { Question } 1 \\
\text { Quality of pain } \\
\text { A. How do you describe your pain in } \\
\text { lumbar spine? }\end{array}$} & Hazy & $0(0.0)$ \\
\hline & Intense & $44(36.4)$ \\
\hline & Superficial & $0(0.0)$ \\
\hline & Deep & $65(53.7)$ \\
\hline & Sharp & $12(9.9)$ \\
\hline & Diffuse & $0(0.0)$ \\
\hline & Located & $0(0.0)$ \\
\hline \multirow{6}{*}{$\begin{array}{l}\text { B. How do you describe your pain in } \\
\text { symptomatic leg? }\end{array}$} & Burning & $8(6.6)$ \\
\hline & Numb & $53(43.8)$ \\
\hline & Sharp & $0(0.0)$ \\
\hline & Shooting & $0(0.0)$ \\
\hline & Pulsing & $0(0.0)$ \\
\hline & As electrical current & $60(49.6)$ \\
\hline \multirow{8}{*}{$\begin{array}{l}\text { Question } 2 \\
\text { Deteriorating factors } \\
\text { What aggravates your pain? }\end{array}$} & Bending & $12(9.9)$ \\
\hline & Raising & $0(0.0)$ \\
\hline & Sitting & $0(0.0)$ \\
\hline & Standing & $45(37.2)$ \\
\hline & Walking & $64(52.9)$ \\
\hline & Lying & $0(0.0)$ \\
\hline & Immobility & $0(0.0)$ \\
\hline & Movement & $0(0.0)$ \\
\hline \multirow{8}{*}{$\begin{array}{l}\text { Question } 3 \\
\text { Relieving factors } \\
\text { What relieves your pain? }\end{array}$} & Bending & $0(0.0)$ \\
\hline & Raising & $0(0.0)$ \\
\hline & Sitting & $0(0.0)$ \\
\hline & Standing & $0(0.0)$ \\
\hline & Walking & $0(0.0)$ \\
\hline & Lying & $113(93.4)$ \\
\hline & Immobility & $8(6.6)$ \\
\hline & Movement & $0(0.0)$ \\
\hline \multirow{4}{*}{$\begin{array}{l}\text { Question } 4 \\
\text { 24-h behavior of pain } \\
\text { When do you feel intense pain? }\end{array}$} & Wakes me up at night & $32(26.4)$ \\
\hline & When falling asleep & $45(37.2)$ \\
\hline & Worst in the morning & $40(33.1)$ \\
\hline & Worst at night & $4(3.3)$ \\
\hline \multirow{2}{*}{$\begin{array}{l}\text { Question } 5 \\
\text { Other symptoms }\end{array}$} & Stiffness / Spasms & $77(63.6)$ \\
\hline & Cramps / Crawling Legs & $44(36.4)$ \\
\hline \multirow{3}{*}{$\begin{array}{l}\text { Question } 6 \\
\text { Other musculoskeletal problems }\end{array}$} & Deformation (Scoliosis/Lordosis/Kyphosis) & $89(73.6)$ \\
\hline & Neck pain & $24(19.8)$ \\
\hline & Leg discrepancy & $8(6.6)$ \\
\hline
\end{tabular}

respectively $(p<0.001)$. The mean fat mass of the symptomatic leg was $22.13 \pm 7.89 \mathrm{~kg}$ and of the asymptomatic leg was $21.31 \pm 7.62 \mathrm{~kg} .(p<0.001)$. The mean percent of water on the symptomatic leg was $54.15 \pm 6.86 \%$ while on the asymptomatic leg $55.17 \pm 6.53 \%(p<0.001)$. Finally, bioelectric impedance conductivity of the symptomatic leg was found to be $499.11 \pm 90.96 \mathrm{~S}$, while on the asymptomatic leg it was 478.22 $\pm 93.26 \mathrm{~S}(p<0.001)$.

\section{DISCUSSION}

In the present study, an attempt was made to map the symptoms of chronic low back pain but also to photograph the status of the patient with the changes of this chronic disease. For this reason, we conducted questionnaires for recording the progress of the pain and the patient's quality of life, clinical assessment, physical function performance tests, and the measurement of biochemical changes in body composition by electrical bioimpedance analysis. To our knowledge, this is the first study to assess all the above-mentioned parameters together.

The most common symptom of low back pain is pain in the lumbar spine, which extends to the hip, buttocks, and along the symptomatic leg. ${ }^{18}$ Our results from the body chart (Questionnaire 1a) showed that the vast 
D. Kechagias et al

Table 3. Questionnaire 2: The Greek FES-I questionnaire results

\begin{tabular}{|c|c|c|c|c|c|}
\hline \multicolumn{6}{|c|}{ How much chronic back pain bothers you... } \\
\hline \multirow{4}{*}{$\begin{array}{l}\text { Question } 1 \\
\text { When doing the housework? }\end{array}$} & Not at all & $0(0.0)$ & \multirow{4}{*}{$\begin{array}{l}\text { Question } 9 \\
\text { When trying to reach something } \\
\text { high? }\end{array}$} & Not at all & $0(0.0)$ \\
\hline & A little & $4(3.3)$ & & A little & $20(16.5)$ \\
\hline & Quite a lot & $20(16.5)$ & & Quite a lot & $48(39.7)$ \\
\hline & A lot & $97(80.2)$ & & A lot & $53(43.8)$ \\
\hline \multirow{4}{*}{$\begin{array}{l}\text { Question } 2 \\
\text { When dressing or undressing? }\end{array}$} & Not at all & $0(0.0)$ & \multirow{4}{*}{$\begin{array}{l}\text { Question } 10 \\
\text { When going to answer the } \\
\text { phone? }\end{array}$} & Not at all & $0(0.0)$ \\
\hline & A little & $24(19.8)$ & & A little & $28(23.1)$ \\
\hline & Quite a lot & $48(39.7)$ & & Quite a lot & $60(49.6)$ \\
\hline & A lot & $49(40.5)$ & & A lot & $33(27.3)$ \\
\hline \multirow{4}{*}{$\begin{array}{l}\text { Question } 3 \\
\text { When preparing food? }\end{array}$} & Not at all & $0(0.0)$ & \multirow{4}{*}{$\begin{array}{l}\text { Question } 11 \\
\text { When walking on a slippery } \\
\text { surface? }\end{array}$} & Not at all & $0(0.0)$ \\
\hline & A little & $52(43.0)$ & & A little & $0(0.0)$ \\
\hline & Quite a lot & $65(53.7)$ & & Quite a lot & $12(9.9)$ \\
\hline & A lot & $4(3.3)$ & & A lot & $109(90.1)$ \\
\hline \multirow{4}{*}{$\begin{array}{l}\text { Question } 4 \\
\text { When taking a bath or shower? }\end{array}$} & Not at all & $8(6.6)$ & \multirow{4}{*}{$\begin{array}{l}\text { Question } 12 \\
\text { When visiting a friend? }\end{array}$} & Not at all & $4(3.3)$ \\
\hline & A little & $44(36.4)$ & & A little & $20(16.5)$ \\
\hline & Quite a lot & $61(50.4)$ & & Quite a lot & $85(70.2)$ \\
\hline & A lot & $8(6.6)$ & & A lot & $12(9.9)$ \\
\hline \multirow{4}{*}{$\begin{array}{l}\text { Question } 5 \\
\text { When going shopping every day? }\end{array}$} & Not at all & $0(0.0)$ & \multirow{4}{*}{$\begin{array}{l}\text { Question } 13 \\
\text { When walking in a crowded } \\
\text { place? }\end{array}$} & Not at all & $0(0.0)$ \\
\hline & A little & $8(6.6)$ & & A little & $4(3.3)$ \\
\hline & Quite a lot & $60(49.6)$ & & Quite a lot & $32(26.4)$ \\
\hline & A lot & $53(43.8)$ & & A lot & $85(70.2)$ \\
\hline \multirow{4}{*}{$\begin{array}{l}\text { Question } 6 \\
\text { When sitting or raising from a } \\
\text { chair? }\end{array}$} & Not at all & $0(0.0)$ & \multirow{4}{*}{$\begin{array}{l}\text { Question } 14 \\
\text { When walking on a rough road? }\end{array}$} & Not at all & $0(0.0)$ \\
\hline & A little & $20(16.5)$ & & A little & $0(0.0)$ \\
\hline & Quite a lot & $48(39.7)$ & & Quite a lot & $4(3.3)$ \\
\hline & A lot & $53(43.8)$ & & A lot & $117(96.7)$ \\
\hline \multirow{4}{*}{$\begin{array}{l}\text { Question } 7 \\
\text { When going up or down stairs? }\end{array}$} & Not at all & $0(0.0)$ & \multirow{4}{*}{$\begin{array}{l}\text { Question } 15 \\
\text { When walking uphill or down- } \\
\text { hill? }\end{array}$} & Not at all & $0(0.0)$ \\
\hline & A little & $0(0.0)$ & & A little & $0(0.0)$ \\
\hline & Quite a lot & $40(33.1)$ & & Quite a lot & $0(0.0)$ \\
\hline & A lot & $81(66.9)$ & & A lot & $121(100.0)$ \\
\hline \multirow{4}{*}{$\begin{array}{l}\text { Question } 8 \\
\text { When walking in the neighbour- } \\
\text { hood? }\end{array}$} & Not at all & $4(3.3)$ & \multirow{4}{*}{$\begin{array}{l}\text { Question } 16 \\
\text { When going to a social event } \\
\text { (e.g. Church)? }\end{array}$} & Not at all & $0(0.0)$ \\
\hline & A little & $32(26.4)$ & & A little & $12(9.9)$ \\
\hline & Quite a lot & 77 (63.6) & & Quite a lot & $73(60.3)$ \\
\hline & A lot & $8(6.6)$ & & A lot & $36(29.8)$ \\
\hline
\end{tabular}

Table 4. Bioimpedance analysis results in all patients

\begin{tabular}{llll}
\hline Parameter & Symptomatic leg & Asymptomatic leg & $p$-value \\
\hline Percent of fat (\%) & $29.85 \pm 9.51$ & $28.73 \pm 9.21$ & $<0.001$ \\
Fat mass (kg) & $22.13 \pm 7.89$ & $21.31 \pm 7.62$ & $<0.001$ \\
Fat free mass (kg) & $53.07 \pm 13.90$ & $53.61 \pm 12.95$ & $<0.001$ \\
Dry lean mass (kg) & $12.65 \pm 4.97$ & $12.42 \pm 4.85$ & 0.092 \\
Water (\%) & $54.15 \pm 6.86$ & $55.17 \pm 6.53$ & $<0.001$ \\
Water (L) & $40.50 \pm 10.06$ & $41.70 \pm 9.90$ & $<0.001$ \\
Net muscle mass (kg) & $26.26 \pm 3.46$ & $26.41 \pm 3.44$ & $<0.001$ \\
Calories resting (cal) & $1634.96 \pm 352.48$ & $1652.52 \pm 346.37$ & $<0.001$ \\
Daily calories need (cal) & $2660.76 \pm 694.82$ & $2688.0 \pm 686.05$ & $<0.001$ \\
BMR & $21.94 \pm 2.86$ & $22.14 \pm 2.86$ & $<0.001$ \\
Conductivity (S) & $499.11 \pm 90.96$ & $478.22 \pm 93.26$ & $<0.001$ \\
\hline
\end{tabular}

BMR: basal metabolic rate 
majority of patients felt low back pain in the left side. Also, patients experienced pain not only in the lumbar spine but also mainly in hip, thigh, and calf, while in areas other than the symptomatology of the disease such as the upper body parts (neck, shoulders, chest, and abdomen) pain was absent. These results are consistent with the common symptomatology of low back pain disease. ${ }^{18,19}$ According to Questionnaire 1b, our results show that chronic pain and/or neurologic stress, both in the lumbar spine and the sciatic nerve, produced symptoms and each time the mechanical loading was above the limits of tissue strength (in ligaments, muscles, spine joints, etc.) the neurological symptoms (numbness, electricity, etc.) arose as described elsewhere. ${ }^{19}$ Questionnaire 2 showed that the symptoms of low back pain determine the pace, intensity and duration of everyday activities. All in all, our results depict that chronic low back pain is a disabling disease which restricts quality of life. Psychological factors may have a larger impact on disability and quality of life than pain itself in accordance with the suggestions of Scolich et al. ${ }^{4}$

The main purpose of clinical examination is to identify the cause of pain, and to check the functionality of the lumbar spine and the symptoms to the lower extremities. ${ }^{20}$ Our results revealed that the left, mainly non-dominant, leg is the most frequent symptomatic leg, indicating that as our activities are performed in a specific way, that seems to create the appropriate circumstances for the onset and development of chronic low back pain.

In general, the three physical functional performance tests determined that patients with chronic low back pain have limited mobility in their daily activities, so as reduced balance and strength which appear different between symptomatic and asymptomatic legs. These results depict the feeling of pain whenever the patient attempts to walk even in his daily activities. Patients also reported that the pain and numbness that reaches the toe of the symptomatic leg increases during walking. Our results in TUG test indicated that patients with chronic low back pain have in general impaired physical condition. It was evident that pain restricted their running ability, which forced them to perform slowly and pay greater attention to their lifting and sitting in order to avoid experiencing more pain as it is reported elsewhere. ${ }^{21}$ We therefore confirm that the determinant factor of decreased mobility in patients with chronic low back pain is the pain itself and its severity. Results of the 30-second sit-to-stand test revealed that the age, the duration of low back pain and the severe symptoms predetermined the frequency of the repeats achieved in the test. In general, all patients displayed limited mobility of the spine and hips, but it was observed that the majority of them employed various strategies to compensate for it. Consequently, patients with chronic low back pain appear with impaired balance due to the attenuation of the symptomatic leg, to be sluggish due to pain and with reduced general fitness due to the chronic symptoms affecting all the neuromuscular structures of the motor system. ${ }^{22}$ Furthermore, patients with chronic low back pain accumu- late fat, have reduced muscle mass and lose fluids (body water) on the symptomatic leg. These results are in agreement with previous studies ${ }^{9,11}$ suggesting that fat mass and distribution are associated with low back pain intensity and disability, indicating that systemic metabolic factors associated with adiposity play a major role in the pathogenesis of low back pain.

\section{CONCLUSIONS}

Chronic low back pain differentiates the circumference of the thigh and the calf of the symptomatic leg with an increased tendency for depositing fat in the symptomatic side (i.e. leg) and for decreasing muscle mass. Patients with chronic low back pain experience pain not only in the lumbar spine but also in hip, thigh, and calf, which act as a barrier to patient's various personal, professional, social, and recreational activities. Chronic low back pain causes several structural changes to the symptomatic leg of the patients leading to 'unstable' walking, reduced balance, and reduced general physical condition. It is clear that further studies using bioimpedance analysis are needed to address the concerns raised by investigating a multifactorial condition such as the chronic low back pain.

\section{REFERENCES}

1. Sielski R, Rief W, Glombiewski JA. Efficacy of biofeedback in chronic back pain: a meta-analysis. Int J Behav Med 2017; 24(1):25-41.

2. Popescu A, Lee H. Neck pain and lower back pain. Med Clin North Am 2020; 104(2):279-92.

3. Gore M, Sadosky A, Stacey BR, et al. The burden of chronic low back pain: clinical comorbidities, treatment patterns, and health care costs in usual care settings. Spine (Phila Pa 1976) 2012; 37(11):E668-77.

4. Scholich SL, Hallner D, Wittenberg RH, et al. The relationship between pain, disability, quality of life and cognitive-behavioural factors in chronic back pain. Disabil Rehabil 2012; 34(23):1993-2000.

5. Kyle UG, Bosaeus I, De Lorenzo AD, et al. Composition of the ESPEN Working Group. Bioelectrical impedance analysis--part I: review of principles and methods. Clin Nutr 2004; 23(5):1226-43.

6. Fujimoto K, Inage K, Eguchi Y, et al. Use of bioelectrical impedance analysis for the measurement of appendicular skeletal muscle mass/ whole fat mass and its relevance in assessing osteoporosis among patients with low back pain: a comparative analysis using dual X-ray Absorptiometry. Asian Spine J 2018; 12(5):839-45.

7. Fujimoto K, Inage K, Eguchi Y, et al. Dual-energy X-ray absorptiometry and bioelectrical impedance analysis are beneficial tools for measuring the trunk muscle mass of patients with low back pain. Spine Surg Relat Res 2019; 3(4):335-41.

8. Wearing SC, Hennig EM, Byrne NM, et al. Musculoskeletal disorders associated with obesity: a biomechanical perspective. Obes Rev 2006; 7(3):239-50.

9. Urquhart DM, Berry P, Wluka AE, et al. 2011 Young Investigator Award winner: Increased fat mass is associated with high levels of low back pain intensity and disability. Spine 2011; 36(16):1320-5. 
10. Hodselmans AP, Dijkstra PU, Geertzen JHB, et al. Nonspecific chronic low back pain patients are deconditioned and have an increased body fat percentage. Int J Rehabil Res 2010; 33(3):268-70.

11. Hussain SM, Urquhart DM, Wang Y, et al. Fat mass and fat distribution are associated with low back pain intensity and disability: results from a cohort study. Arthritis Res Ther 2017; 19:26.

12. Melzack R. The McGill Pain Questionnaire: major properties and scoring methods. Pain 1975; 1(3):277-99.

13. Billis E, Strimpakos N, Kapreli E, et al. Cross-cultural validation of the Falls Efficacy Scale International (FES-I) in Greek community-dwelling older adults. Disabil Rehabil 2011; 33(19-20):1776-84.

14. Dalton M, Cameron AJ, Zimmet PZ, et al., and AusDiab Steering Committee. Waist circumference, waist-hip ratio and body mass index and their correlation with cardiovascular disease risk factors in Australian adults. J Intern Med 2003; 254(6):555-63.

15. Rikli RE, Jones CJ. Development and validation of a functional fitness test for community-residing older adults. J Aging Phys Act 1999; 7(2):129-61.
16. Briggs RC, Gossman MR, Birch R, et al. Balance performance among noninstitutionalized elderly women. Phys Ther 1989; 69(9):748-56.

17. Podsiadlo D, Richardson S. The timed "Up \& Go": a test of basic functional mobility for frail elderly persons. J Am Geriatr Soc 1991; 39(2):142-8.

18. Chou R. Low back pain (chronic). BMJ Clin Evid 2010; 2010:1116.

19. Bogduk N. On the definitions and physiology of back pain, referred pain, and radicular pain. Pain 2009; 147(1-3):17-9.

20. Waddell G, Somerville D, Henderson I, et al. Objective clinical evaluation of physical impairment in chronic low back pain. Spine (Phila Pa 1976) 1992; 17(6):617-28.

21. Sung PS, Yoon B, Lee DC. Lumbar spine stability for subjects with and without low back pain during one-leg standing test. Spine (Phila Pa 1976) 2010; 35(16):E753-60.

22. Shum GLK, Crosbie J, Lee RYW. Effect of low back pain on the kinematics and joint coordination of the lumbar spine and hip during sit-to-stand and stand-to-sit. Spine (Phila Pa 1976). 2005; 30(17): 1998-2004. 


\title{
Эфрфективность анализа биоэлектрического импеданса для оценки фризических нарушений при хронической боли в пояснице. Результаты когортного исследования.
}

\author{
Димитриос Кекагиас, Кристос Катципапас, Макрина Караглани, Константинос Тилкеридис, \\ Атанасиос Верверидис, Георгиос Дросос \\ Кафедра ортопедической хирургии, Медицинский факультет, Фракийский университет имени Демокрита, Университетская больница \\ Александруполиса, Александруполис, Греция
}

Адрес для корреспонденции: Макрина Караглани, Кафедра ортопедической хирургии, Медицинский факультет, Фракийский университет имени Демокрита, Университетская больница Александруполиса, Александруполис, Греция; E-mail: makrina.karaglani@gmail.com

Дата получения: 4 октября 2020 Дата приемки: 13 января $2021 \bullet$ Дата публикации: 31 декабря 2021

Образец цитирования: Kechagias D, Chatzipapas C, Karaglani M, Tilkeridis K, Ververidis A, Drosos G. Efficacy of bioelectrical impedance analysis for the evaluation of physical impairment in chronic low back pain. Results from a cohort study. Folia Med (Plovdiv) 2021;63(6):919-27. doi: 10.3897/folmed.63.e59311.

\section{Резюме}

Введение: Определение влияния состава тела на хроническую боль в пояснице, по-видимому, может улучшить наше понимание её механизма и разработать новые профилактические и терапевтические подходы.

Цель: Целью настоящего исследования было оценить с помощью электрического импеданса состав нижних конечностей людей с хронической болью в пояснице.

Материалы и методы: В это исследование был отобран 121 взрослый участник с диагностированной хронической болью в пояснице. Исследования были разделены на три фазы: фаза 1 - анкеты для самостоятельного заполнения, фаза 2 - биомедицинское обследование (включая антропометрические измерения и тесты на эффективность физических функций) и фаза 3 - анализ биоимпеданса.

Результаты: Наши результаты показали, что хроническая боль в пояснице различается по окружности бедра и голени симптомной ноги. Кроме того, пациенты также испытывают боль в бедре, бедре и икре, которая препятствует личной, профессиональной, социальной и досуговой деятельности пациента. Кроме того, у пациентов наблюдается нестабильная походка, нарушение равновесия и общее физическое состояние, что влияет на все нервно-мышечные структуры опорно-двигательного аппарата. Интересно отметить, что пациенты имеют тенденцию к накоплению жировой ткани и уменьшению мышечной массы симптоматической конечности независимо от пола.

Заключение: В настоящем исследовании мы построили профиль пациента с хронической болью в пояснице с помощью различных измерений. Хроническая боль в пояснице вызывает несколько структурных изменений симптоматических конечностей пациентов, что приводит к нестабильной походке, ухудшению равновесия и ухудшению общего физического состояния. Очевидно, что необходимы дальнейшие исследования с анализом биоимпеданса для решения проблем, вызванных многофакторным заболеванием, таким как хроническая боль в пояснице.

\section{Ключевые слова}

биоимпедансный анализ, состав тела, боль в пояснице 